\title{
Wogonin reverses the drug resistance of chronic myelogenous leukemia cells to imatinib through CXCL12-CXCR4/7 axis in bone marrow microenvironment
}

\author{
Hanbo Cao", Yuan Gao", Ruixuan Wang, Qinglong Guo, Hui Hui \\ State Key Laboratory of Natural Medicines, Jiangsu Key Laboratory of Carcinogenesis and Intervention, China Pharmaceutical University, Nanjing, \\ China \\ Contributions: (I) Conception and design: H Hui, Q Guo; (II) Administrative support: Q Guo, H Hui; (III) Provision of study materials or patients: H \\ Cao, R Wang; (IV) Collection and assembly of data: Y Gao, H Hui; (V) Data analysis and interpretation: H Cao, H Hui; (VI) Manuscript writing: All \\ authors; (VII) Final approval of manuscript: All authors. \\ \#These authors contributed equally to this work. \\ Correspondence to: Qinglong Guo; Hui Hui. State Key Laboratory of Natural Medicines, Jiangsu Key Laboratory of Carcinogenesis and Intervention, \\ China Pharmaceutical University, 24 Tongjiaxiang, Nanjing, China. Email: anticancer_drug@163.com; moyehh@163.com.
}

Background: In the current study, chronic myeloid leukemia (CML) cells (K562 and KU812) co-cultured with human bone marrow stromal cells (BMSCs) were significantly less sensitive to imatinib (IM). The activation of the CXCL12-CXCR4/7 axis plays an important role in the protective effect of the bone marrow microenvironment (BME) on CML cells. The aim of this study was to investigate whether Wogonin could increase the sensitivity of CML cells to IM when they were co-cultured with BME and explore its underlying mechanism.

Methods: A model of CML cells co-cultured with BMSCs was applied in vitro. Flow cytometric, western blotting, immunofluorescence, and RT-PCR assays were used to explore the protective effects of BME on CML cells.

Results: The results showed that Wogonin could reverse the resistance of CML cells to IM under coculture conditions by inhibiting Transforming growth factor- $\beta$ (TGF- $\beta$ ) secretion in the BME, preventing the translocation of Smad4 into nucleus and subsequently reducing the expression of CXCR4 and CXCR7 in CML cells. Moreover, the reverse effect of Wogonin was demonstrated by inhibiting the activation of CXCL12-CXCR4/7 axis via restraining the TGF- $\beta / S m a d 4 / I d 3$ pathway in vitro. In vivo studies also showed that Wogonin decreased the expression of CXCR4 and CXCR7 in mice bone marrow with low systemic toxicity, and the mechanism was consistent with the in vitro study.

Conclusions: Wogonin increases the sensitivity of CML cells to IM in BME by controlling the TGF- $\beta$ / Smad4/Id3 pathway and decreasing the expression of CXCR4 and CXCR7. These results co-supported the point that Wogonin could be a potential candidate of reversal agents on treatment of IM-resistant CML.

Keywords: Chronic myeloid leukemia (CML); bone marrow (BM); Wogonin; imatinib (IM)

Submitted Feb 02, 2020. Accepted for publication Aug 05, 2020.

doi: 10.21037/atm-20-1166

View this article at: http://dx.doi.org/10.21037/atm-20-1166

(c) Annals of Translational Medicine. All rights reserved. 


\section{Introduction}

Chronic myeloid leukemia (CML) is driven by the $\mathrm{t}(9 ; 22)$ (q34.1; q11.2) chromosomal translocation, resulting in the expression of BCR/ABL oncoprotein (a constitutively active tyrosine kinase) expression. Currently, chronic-phase CML patients are treated with imatinib-mesylate (IM), a tyrosine kinase inhibitor (TKI) targeting the BCR/ABL (1-3). However, in the course of treatment, about $30 \%$ of patients will develop IM resistance (4).

The bone marrow microenvironment (BME) has proven to play a vital role in cell differentiation, migration, proliferation, survival, and drug resistance of leukemia cells. BME could protect leukemia cells from TKIs-induced apoptosis $(5,6)$. CXCL12 (SDF-1 $\alpha$, stromal derived factors$1 \alpha)$ is a chemokine mainly secreted by the BME. It supports the proliferation and survival of various malignancies, such as CML, acute myeloid leukemia (AML), multiple myeloma and lymphoma (7-11). CXCR4 and CXCR7, two seventransmembrane G-protein-coupled chemokine receptors, are capable of mediating homing, proliferation, invasion and metastasis of tumor cells and regulating the resistance induced by soluble factors (12).

TGF- $\beta$ is a multifunctional growth factor that regulates various cellular activities in a cell-dependent manner (13). In the present study, TGF- $\beta$ is expressed in human bone marrow stromal cells (hBMSCs), and connected with its functional receptors, including TGF- $\beta$ receptor type I (TGF- $\beta$ RI) and TGF- $\beta$ receptor type (TGF- $\beta$ RII) (14). TGF- $\beta$ RI is activated to induce phosphorylation of Smad family proteins to initiate downstream signaling pathways in the cell (15). Dissociates from the receptor when Smads is phosphorylated and forms an oligomeric complex with Smad4 in the cytoplasm. Then, the R-Smad/Smad4 complex enters the nucleus and interacts with DNA-binding transcription factors $(16,17)$. It can regulate the inhibitors of DNA binding/differentiation (Ids) in a cell-type-specific manner and play critical roles in animal development and cancer $(18,19)$.

Wogonin is a naturally monoflavonoid compound extracted from the traditional Chinese medicine Scutellaria baicalensis. It is reported to have biological functions with antibacterial, antiviral, antioxidant, anticancer, and neuroprotective activities (20,21). Previous work demonstrates that Wogonin reverses drug resistance of human CML cells in BME (22).

It was found in our previous research that Wogonin could reverse IM resistance in CML cells by inhibiting the

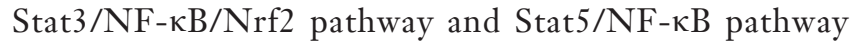
$(22,23)$. Here we evaluated whether Wogonin could regulate the expression of CXCR4/7 in CML cells to enhance the sensitivity of CML cells to IM in the cocultured condition.

We present the following article in accordance with the ARRIVE reporting checklist (available at http://dx.doi. org/10.21037/atm-20-1166).

\section{Methods}

\section{Reagents and antibodies}

Wogonin (99\% purity; Langze Pharmaceutical Co., Ltd., Nanjing, China) was dissolved in dimethyl sulfoxide (DMSO) as a stock solution $(100 \mathrm{mM})$, stored at $-20^{\circ} \mathrm{C}$, and diluted to each of the designated concentrations in the buffer solution before each experiment. The final concentration of DMSO did not exceed $0.1 \%$. The culture medium was RPMI-1640 and DMEM/F12 (1:1) (Gibco, Invitrogen Corporation, Carlsbad, CA, USA). DAPI (Invitrogen, USA) was used to detected apoptosis cells. The final concentration of DMSO did not exceed $0.1 \%$ throughout the study. Primary antibodies against GAPDH $(1: 10,000)$, CXCR7 and CXCR4 $(1: 1,000)$ were products from Bioworld (OH, USA). Primary antibodies against caspase $3(1: 1,000)$, caspase $9(1: 1,000)$, ERK (1:500), p-ERK (1:500), Akt (1:1,000), p-Akt $(1: 1,000)$, Smad4 $(1: 1,000)$ MEK $(1: 1,000)$ and p-MEK $(1: 1,000)$ were obtained from Cell Signaling Technology (Danvers, MA, USA). Primary antibody against Actin $(1: 10,000)$ was obtained from Santa Cruz Biotechnology (Santa Cruz, CA, USA). HRP goat anti-rabbit lgG and anti-mouse $\lg \mathrm{G}$ $(1: 20,000)$ was purchased from ABclonal (ABclonal, China). IM was purchased from Melonepharma (Dalian, China). Id 2 and Id 3 small interfering RNA (siRNA) was purchased from Santa Cruz Biotechnology, Inc (Santa Cruz, CA, USA). LY 320082 was purchased from Selleck (Selleck Chemicals, USA).

\section{BMSCs isolation and culture}

BMSCs were isolated from the iliac crest bone marrow aspirates of healthy donors after informed consent was obtained. The study was conducted in accordance with the Declaration of Helsinki (as revised in 2013). The study was approved by Nanjing Drum Tower Hospital's institutional review board. Bone marrow mononuclear cells were isolated 
by Percoll (Solarbio, USA), Dulbecco's modified Eagle's medium (DMEM) (Euroclone, USA) with $1,000 \mathrm{mg} / \mathrm{mL}$ glucose and L-glutamine, centrifuged and plated at a density of 1,000 cells $/ \mathrm{cm}^{2}$. BMSCs were cultured in L-DMEM/ F12 (GIBCO, USA) with 15\% fetal bovine serum (GIBCO, USA) at $37{ }^{\circ} \mathrm{C}$ with $5 \% \mathrm{CO}_{2}$. Four days later, non-adherent cells were removed carefully, and the culture medium was refreshed. When primary cultures became almost confluent, the culture was treated with $0.5 \mathrm{~mL}$ of $0.25 \%$ trypsin containing $0.02 \% \mathrm{mmol} / \mathrm{L}$ ethylenediamine tetraacetic acid (GIBCO, USA) for $4 \mathrm{~min}$ at room temperature $\left(25^{\circ} \mathrm{C}\right)$. A purified population of BMSCs was obtained 1 week after the initiation of culture.

\section{Cell line and culture conditions}

Human CML cell line K562 and KU812 were purchased from Cell Bank of Shanghai Institute of Biochemistry \& Cell Biology at September 2017. All cell lines were authenticated based on STR fingerprinting and last checked in August 2014. Cells were cultured in RPMI-1640 medium supplemented with $10 \%$ heat-inactivated fetal bovine serum (GIBCO, USA), in a humidified environment with $5 \% \mathrm{CO}_{2}$ at $37^{\circ} \mathrm{C}$.

\section{Flow cytometric analysis of apoptosis}

Apoptosis was evaluated using an annexin V-FITC/ propidium iodide (PI) Apoptosis Detection Kit (KeyGEN BioTECH, Nanjing, China) according to the manufacturer's instruction. Cellular fluorescence was measured by flow cytometric analysis using a FACS Calibur flow cytometer (Becton Dickinson Biosciences, Franklin Lakes, USA), according to the descriptions in our previous research. Cells in the early stage of apoptosis were annexin $\mathrm{V}$ positive and PI negative, whereas cells in the late stage of apoptosis were both annexin $\mathrm{V}$ and PI positive.

\section{Western blot analysis}

Cells were collected and lysed in lysis buffer [50 mM Tris$\mathrm{HCl}, \mathrm{pH}$ 7.6, $150 \mathrm{mM} \mathrm{NaCl}, 1 \mathrm{mM}$ EDTA, $1 \%$ (m/v) NP40, $0.2 \mathrm{mM}$ phenylmethanesulfonyl fluoride (PMSF), 0.1 $\mathrm{mM} \mathrm{NaF}$, and $1.0 \mathrm{mM}$ dithiothreitol]. The lysates were centrifuged at $4{ }^{\circ} \mathrm{C}$ for $30 \mathrm{~min}$ at $12,000 \times \mathrm{g}$. The supernatant was used to determine the protein concentration by bicinchoninic acid (BCA) assay kit (Pierce, Rockford, USA) with a Varioskan multimode microplate spectrophotometer
(Thermo Waltham, MA, USA). Protein samples were loaded on $10 \%$ SDS-PAGE gel and transferred to nitrocellulose membranes (BioTrace NT, PallCor, USA). The membranes were then blocked with $1 \%$ BSA in PBS for $1 \mathrm{~h}$, followed by incubating with primary antibodies at $4{ }^{\circ} \mathrm{C}$ overnight. After three washes with PBST, the membrane was incubated with HRP goat anti-rabbit IgG or anti-mouse $\operatorname{IgG}$ conjugated second antibody for $1 \mathrm{~h}$ at room temperature. Detection was performed with an Amersham Imager 600 RGB (GE, USA).

\section{Immunofluorescence confocal microscopy}

Treated CML cells were harvested and seeded onto glass coverslips specially prepared for immunofluorescence. After washing twice with cold PBS for 5 min, cells were fixed with $4 \%$ paraformaldehyde (PFA) for $25 \mathrm{~min}$, and permeabilized with PBS containing $0.2 \%$ Triton X-100 for $25 \mathrm{~min}$. Then, the cells were blocked with $3 \%$ BSA in PBS for $1 \mathrm{~h}$ and incubated with anti-Smad4 antibody (1:50) at $4{ }^{\circ} \mathrm{C}$ overnight. After washing thrice with PBS for $5 \mathrm{~min}$, the cells were stained with FITC-conjugated anti-rabbit IgG antibody $(1: 200)$ at $37^{\circ} \mathrm{C}$ for $1 \mathrm{~h}$. After counterstaining with DAPI (Invitrogen, USA) for $20 \mathrm{~min}$, the images were captured with an Olympus FV1000 confocal microscope.

\section{Immunobistochemistry}

Marrow samples were removed from both physiological saline and Wogonin and IM combination treated or alone. The expression of CXCR7 and CXCR4 were assessed by immunohistochemical method using a rabbit-antihuman monoclonal antibody and an Ultra-Sensitive ${ }^{\text {TM }}$ SP kit (kit 9710 MAIXIN, Fuzhou, China). Tissue sections (4- $\mu \mathrm{m}$ thick) were placed onto treated slides (Vectabond, Burlingame, California, USA). Sections were fixed in a $60{ }^{\circ} \mathrm{C}$ incubator, deparaffinized and rehydrated through graded alcohols (100\%, 95\%, $85 \%$, and $75 \%)$. Tissue sections were boiled in citrate buffer at high temperature for antigen retrieval and treated with $3 \%$ hydrogen peroxide to block endogenous peroxidase activity. The slides were incubated with a protein-blocking agent (kit 9710 MAIXIN, Fuzhou, China) prior to the application of the primary antibody, and then incubated with the primary antibody at $4{ }^{\circ} \mathrm{C}$ overnight. The tissues were then incubated with the secondary biotinylated anti-species antibody and labeled using a modification of the avidinbiotin complex immunoperoxidase staining according to 
the UltraSensitive ${ }^{\mathrm{TM}}$ SP kit manual. Counterstaining was done with Harris hematoxylin. Images were captured using a camera attached to computer.

\section{siRNA transient transfection}

The transient transfection assay was carried out in 6-well plates using PepMute ${ }^{\mathrm{TM}}$ siRNA Transfection Reagent (SignaGen ${ }^{\circledR}$ Laboratories, USA) according to the manufacturer's instruction. First, PepMute ${ }^{\mathrm{TM}}$ transfection buffer was diluted before use, and then $3.3 \mu \mathrm{L}$ siRNA in $1 \mathrm{~mL}$ RPMI 1640 medium was added gently and incubated for $15 \mathrm{~min}$ at room temperature. The complexes were added to each well and mixed gently by rocking the plates back and forth. The plates were then incubated at $37^{\circ} \mathrm{C}$ in a $\mathrm{CO}_{2}$ incubator. After $48 \mathrm{~h}$, cells were collected for further experiments. The Id 2 and Id 3 siRNA product was purchased from Santa Cruz Biotechnology, Inc. (Santa Cruz, CA, USA).

\section{Animal experiment}

The animal study was carried out according to the regulations of China Food and Drug Administration (CFDA) on Animal Care. This study was reviewed and approved by Animal Care Use Committee of Jiangsu Province (Animal authorization reference number: SYXK2012-0035). Male NOD/SCID mice (35-40 days old, weighing 18-22 g) were supplied by the Model Animal Research Center of Nanjing University. The mice were raised in air-conditioned rooms under controlled lighting (12 h lighting/d) and were fed with standard laboratory food and water. K562 cells were cultured for $60 \mathrm{~h}$ with or without hBMSCs. Subsequently, K562 and co-cultured cells $\left(5 \times 10^{6} \mathrm{cell} / \mathrm{mL}\right)$ were injected into each mouse via tail vein. The NOD/SCID mice with similar weight were randomly divided into six groups: negative control (normal mice), control (transplanted with K562 cells), co-culture group (transplanted with K562 and hBMSCs), IM monotreatment (transplanted with K562 cells or co-transplanted) and combination group (co-treated with IM and Wogonin in co-transplanted) $(\mathrm{n}=5)$. Four weeks later, the mice were treated with Wogonin $(200 \mathrm{mg} / \mathrm{kg})$, and IM $(200 \mathrm{mg} / \mathrm{kg})$ (Sigma Aldrich, US) alone or in combination. After treatment for 30 days, marrow contents of femurs were obtained. These cells were labelled with anti FITC-CD45 (eBioscience, California, USA) antibody and analyzed by flow cytometry.

\section{Statistical analysis}

The data were expressed as the mean \pm standard deviation (SD) from at least three independent experiments. Significant differences between groups were determined by one-way analysis of variance followed by post hoc Tukey's test by GraphPad prism 7. ${ }^{*} \mathrm{P}<0.05,{ }^{*} \mathrm{P}<0.01$ and ${ }^{* * *} \mathrm{P}<0.001$ indicated significant differences compared with control group.

\section{Results}

\section{Wogonin could enhance the sensitivity of CML cells to IM} in the BME

In order to simulate BME in vitro, we established a co-culture model by co-cultivating CML cells with hBMSCs (24). Our previous research has shown that human BME could protect CML cells from IM-induced apoptosis (25). Firstly, MTT assay and annexin V/PI double-staining assay were used to evaluate the toxicity of Wogonin on K562 and KU812 cells under co-culture conditions, and appropriate concentration of Wogonin in our research were obtained based on the results. The concentrations of 10 and $20 \mu \mathrm{M}$ showed neither cytotoxicity (Figure 1A) nor apoptosis rate (Figure 1B), so the concentration of $20 \mu \mathrm{M}$ was used in further tests. Apoptosis rate of K562 and KU812 cells treated with Wogonin and IM was increased compared with that in the cells treated with IM alone (Figure 1C). The expression of Ki67 in combination group was less than that in IM alone under coculture condition (Figure 1D). Western blot results showed that the level of cleaved-caspase 3 and cleaved-caspase 9 were augmented in combination group (Figure 1E,F). The above results indicated that Wogonin was able to reverse the resistance of CML cells to IM in co-culture condition.

\section{Wogonin could reverse the activation of CXCL12- CXCR4/7 axis in CML cells with BME}

According to our previous research, the protective effect of BME on CML cells may be attributed to the activation of CXCR4 and CXCR7 receptors whose downstream effectors can promote the survival of CML cells $(26,27)$. In order to further explore the mechanism of action of Wogonin, Western blots assay was used to detect the activation of CXCR4/Akt and CXCR7/MEK/ERK signal pathways. Figure $2 A, B, C$ showed that the combination group under co-culture condition, the regulation of the downstream 
A

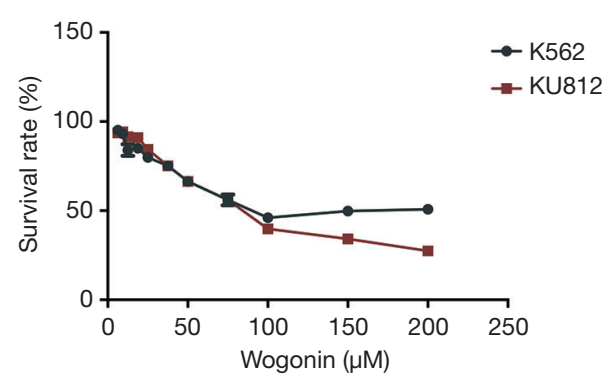

C

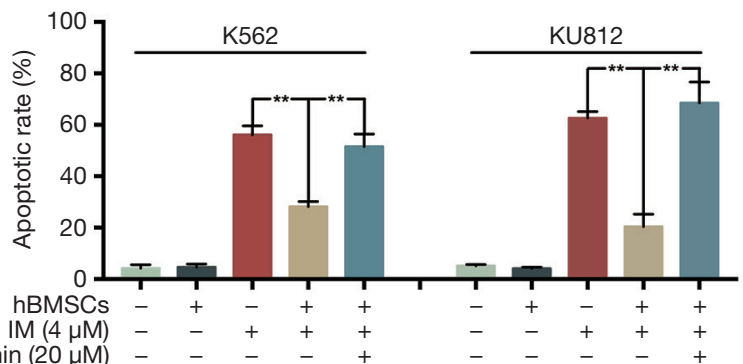

B

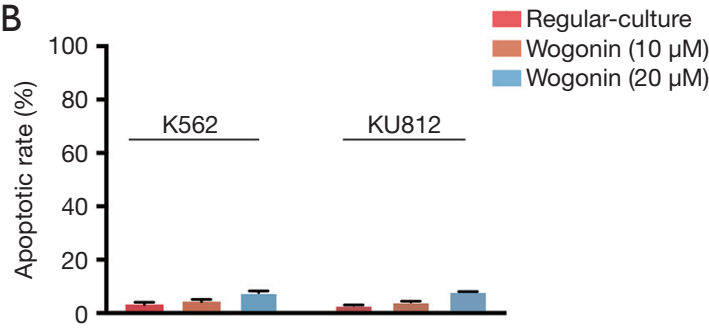

D
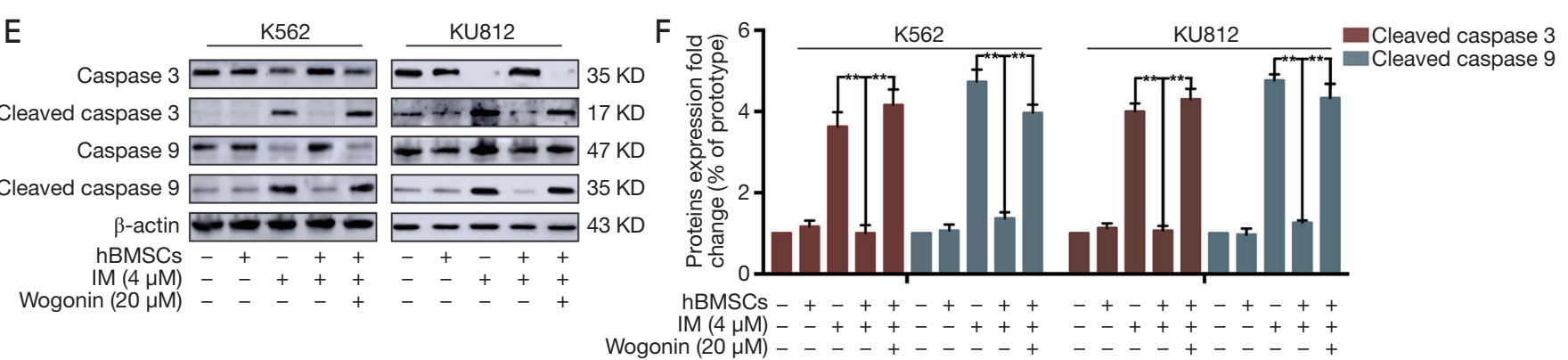

Figure 1 Wogonin reversed the effect of protection of hBMSCs on CML cells. (A) Growth survival of Wogonin treatment for $48 \mathrm{~h}$ on CML cells was assessed by MTT assay. (B) Apoptosis rate of K562 and KU812 cells after treatment by Wogonin (10 and $20 \mu \mathrm{M})$. K562 and KU812 cells were cultured with or without IM and Wogonin in normal group or co-culture group for $48 \mathrm{~h}$. Cell proliferation was determined by annexin V/PI double-staining assay and Ki67 cell proliferation detection. (C) Percentage of apoptosis in K562 and KU812 cells after treatment. (D) Ki67 cell proliferation detection (original magnification, $\times 10$ ). (E) The expression of cleaved-caspase 3 and 9 was determined using Western blot analysis. (F) Analysis of proteins expression. ${ }^{* *}, \mathrm{P}<0.01$. hBMSCs, human bone marrow stromal cells; CML, chronic myeloid leukemia.

proteins of CXCR4 and CXCR7 were reduced significantly. Meanwhile, our RT-PCR analysis also showed significantly decrease in CXCR4 and CXCR7 mRNA levels in combination group under co-culture condition (Figure 2D).

\section{The expression of CXCR4 and CXCR7 was regulated by TGF- $\beta$ in CML cells cultured in buman BME}

Chu et al. reported that TGF- $\beta$ could induce up-regulation of CXCR4 expression in human basal cell carcinoma (BCC) cells (28). In order to further explore the specific mechanism of the up-regulation of CXCR4 and CXCR7 in co-culture condition, we first examined the concentration of TGF- $\beta$ at different time points $(0,12,24,36$ and $48 \mathrm{~h})$ in CML cells co-cultured with or without BMSCs (Figure 3A). When cocultured with BMSCs, the secretion of TGF- $\beta$ by CML cells was increased in a time-dependent manner, while the concentration of TGF- $\beta$ was low in culture medium of CML cells or BMSCs respectively. We also examine the changes in CXCR4 and CXCR7 expression in different dose of TGF- $\beta(5,10 \mathrm{ng} / \mathrm{mL})$ and time point $(48 \mathrm{~h})$, respectively to make a comparison with regular-culture (Figure 3B). We found that the mRNA level of CXCR4 and CXCR7 elevated sharply after TGF- $\beta(10 \mathrm{ng} / \mathrm{mL})$ exposure 
A

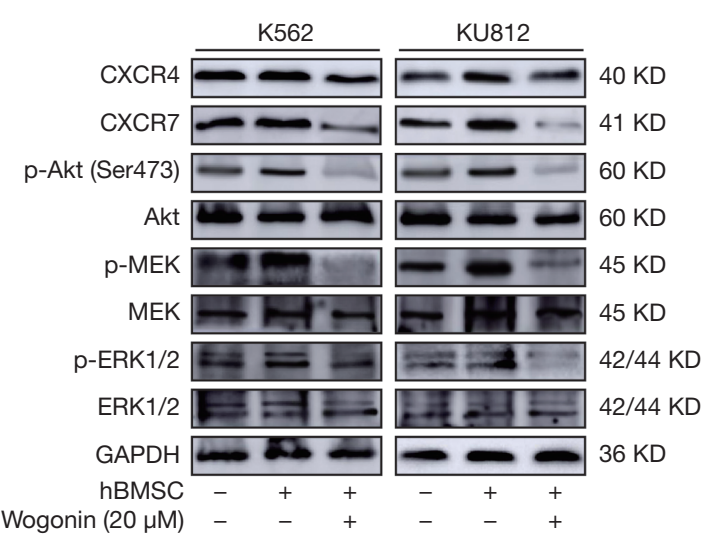

B
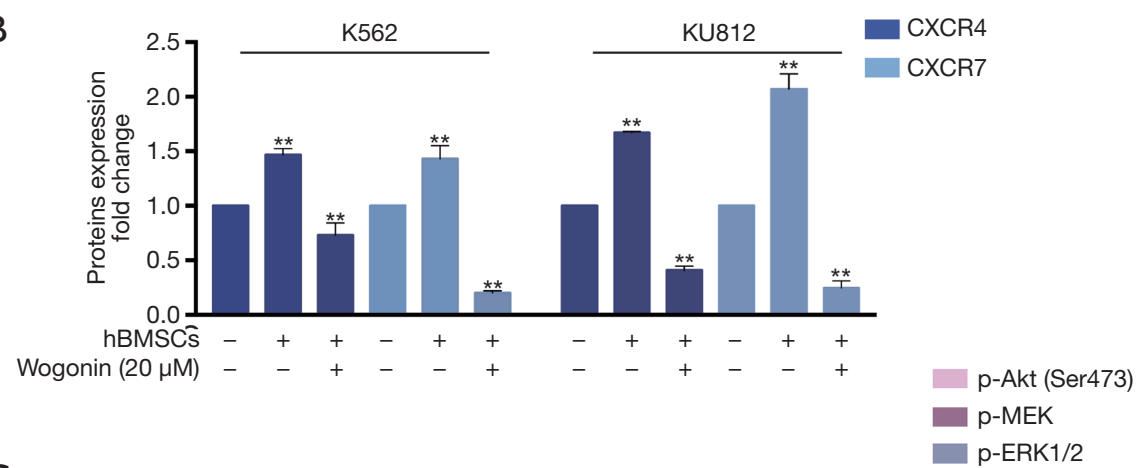

C
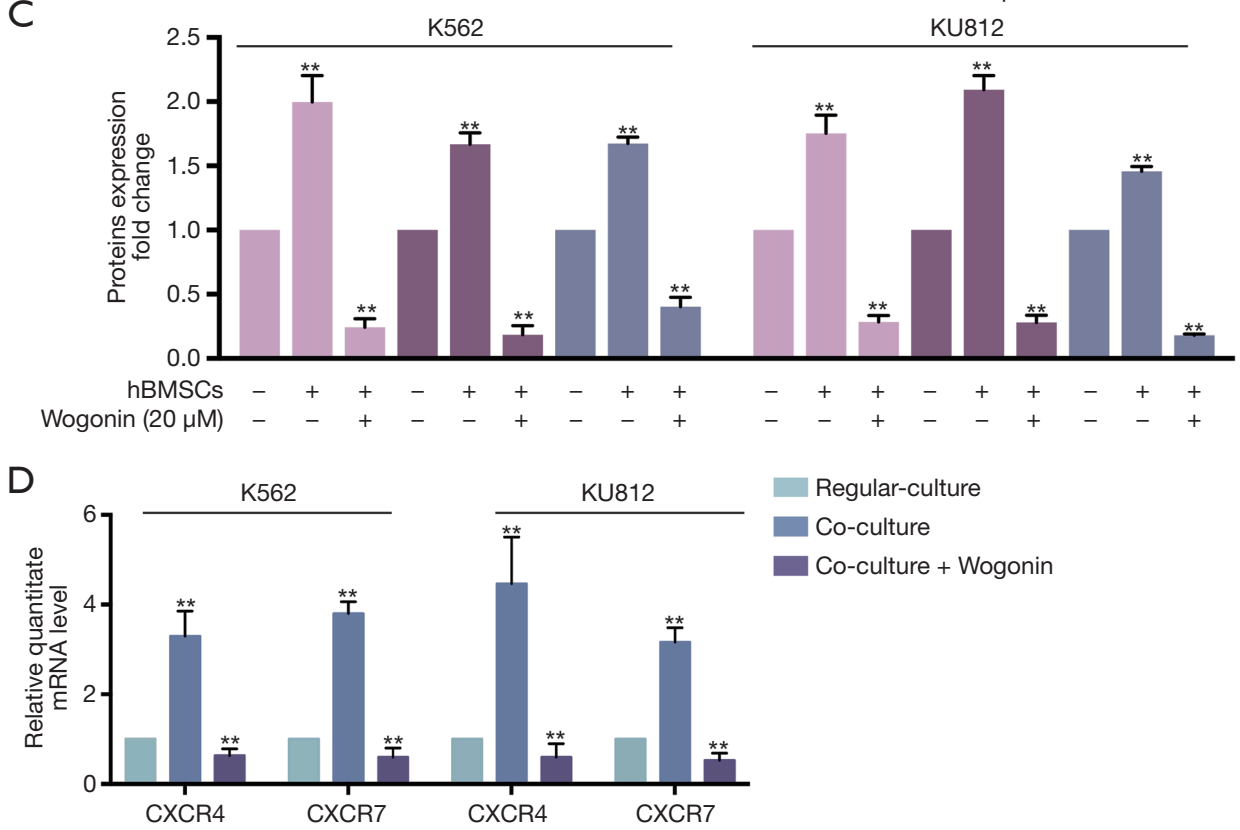

Figure 2 Bone marrow microenvironment activates CXCR4 and CXCR7 in CML cells and Wogonin can reverse it. K562 and KU812 cells were cultured with or without hBMSCs for $48 \mathrm{~h}$ treatment with Wogonin. (A) The expression of downstream protein of CXCR4 and CXCR7 was analyzed by western blot analysis. (B) Analysis of CXCR4 and CXCR7 proteins expression. (C) Analysis of p-Akt, p-MEK and p-ERK1/2 proteins expression. (D) CXCR4 and CXCR7 mRNA expression was detected by RT-PCR assay. ${ }^{* *}$, P<0.01. hBMSCs, human bone marrow stromal cells; CML, chronic myeloid leukemia. 
within $48 \mathrm{~h}$. Western blot assay was detected in response to the levels of CXCR4 and CXCR7 generation (Figure 3C,D). Either CXCR4 or CXCR7 expression in TGF- $\beta$-treated CML cells was two folds more than that of untreated cells. We may conclude that TGF- $\beta$ could enhance the CXCR4 and CXCR7 expression in CML cells.

And then, we explored the activation state of TGF- $\beta$ downstream signals. With $48 \mathrm{~h}$ treatment of TGF- $\beta$ on CML cells, the amount of Smad4 was notably escalated in nucleus, as shown in Figure 3E,F. LY 320082, the inhibitor of TGF$\beta R I$, has the opposite effect. Immunofluorescence staining with antibody to Smad4 showed its localization in tumor cell nucleus (Figure 3G). The results above showed that Smad4 was activated either by employing TGF- $\beta$ or co-cultured with hBMSCs. As shown in Figure 3H,I,7, the BME up-regulated the mRNA and protein expression of CXCR4 and CXCR7 by activating TGF- $\beta$ RI. In addition, LY 320082 could suppress this effect. Taken together, we believed that TGF- $\beta$ could regulate the expression of CXCR4 and CXCR7.

\section{Id3 activation played an exceptional part in the TGF- $\beta$ - mediated CXCR4 and CXCR7 generation in CML cells}

Although TGF- $\beta$ could trigger response in several cells via activation of the Smads cascade, there were insufficient research on the regulation of CXCR4/7 by Smad4 signaling. Reports elaborated the regulation of CXCR4/7 by Ids, the downstream effector of TGF- $\beta$ (29). Therefore, we intend to explore whether TGF- $\beta$ could modulate CXCR4 and CXCR7 via Id family in CML cells. Compared with regular culture, co-culture could enhance the secretion of TGF- $\beta$, which subsequently elevated the level of Id 2 and Id 3 by RTPCR analysis. In consistent with that, exogenous TGF- $\beta$ could also increase Id 2 and Id 3 expression (Figure $4 A$ ). To investigate the effect of $\operatorname{Id} 2 / 3$ on the expression of CXCR4/7, we utilized siRNA to knock down Id2 and Id 3 respectively (Figure $4 B$ ). Interestingly, Id 2 knockdown did not influence on the expression of CXCR4/7 while Id3 knock-down decreased the level of CXCR4/7. In the presence or absence of TGF- $\beta$, Id 2 knock-down did not affect the effect of TGF- $\beta$ to CXCR4/7 in CML cells. However, TGF- $\beta$ fail to elevate the level of CXCR4/7 after Id3 was knocked down in CML cells (Figure 4C,D).

\section{The inhibitory effect of Wogonin on CXCR4 and CXCR7 was mediated via the TGF- $\beta / I d 3$ signal}

According to our previous research, the effect of BME on
CML cells is mainly due to the activation of CXCR4 and CXCR7 receptors $(25,30)$. As demonstrated above, we have already clarified that the survival mechanism of CML cells in co-culture system was due to the activation of CXCR4/7 by TGF- $\beta / \mathrm{Id} 3$ signal. Since Wogonin could enhance the sensitivity of CML cells to IM in the bone marrow environment, we want to ask whether the effect of Wogonin on IM-resistant CML cells could also be attributed to TGF- $\beta / \mathrm{Id} 3$ mediated CXCR4/7 activation. After treating the cells with Wogonin in the co-culture system for $48 \mathrm{~h}$, the secretion of TGF- $\beta$ by ELISA analysis was decreased and nuclear Smad4 of CML cells reduced simultaneously (Figure 3E,F and Figure 5A). Results of RT-PCR showed that the increase of Id $3 \mathrm{mRNA}$ in the co-culture system was significantly inhibited by Wogonin (Figure 5B). Western blot also showed that CXCR4/7 were down-regulated after Wogonin treatment (Figure 3C,D). Moreover, Id3 overexpression could elevate CXCR4/7 protein level but not influence the secretion of TGF- $\beta$ (Figure 5C,D). Overexpression of $\mathrm{Id} 3$ could also eliminate the activating effect of Wogonin on CXCR4/7 in CML cells (Figure 5E,F). Taken together, Wogonin could decrease the expression of CXCR4/7 via down-regulating TGF- $\beta / \mathrm{Id} 3$ signal in CML cells.

\section{Wogonin inbibited the protective effect of BME on CML cells by down-regulating the expression of CXCR4 and CXCR7 in vivo}

CML mice model was utilized to assess the effect of combination treatment of IM and Wogonin. Figures $6 \mathrm{~A}$ showed that the weight of mice remained stable in combination treatment group compared with IM alone. As shown in Figure 6B, the combination group had a great advantage over others in terms of survival. Nine weeks after transplantation, significant splenomegaly was observed in the spleens of the mice in negative control group. Compared with the IM treatment group, the combination treatment group could significantly ameliorate the phenomenon of splenomegaly. (Figure 6C,D). As shown in Figure 6E,F, the expression of CD45 in mice bone marrow cells of combined group was significantly lower than that of IM alone. Figure $6 G$ showed that the increased expression of CXCR4 and CXCR7 in co-culture group in thigh bones may be responsible for IM resistance. Therefore, we concluded that combination of Wogonin and IM can significantly inhibit tumor growth via decreasing the expression of CXCR4 and CXCR7 in vivo. 


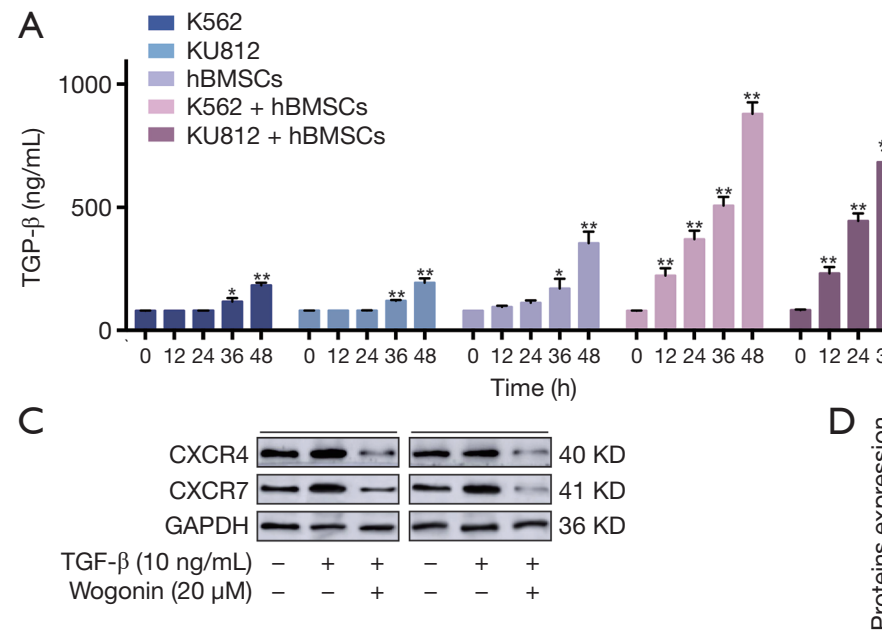

B

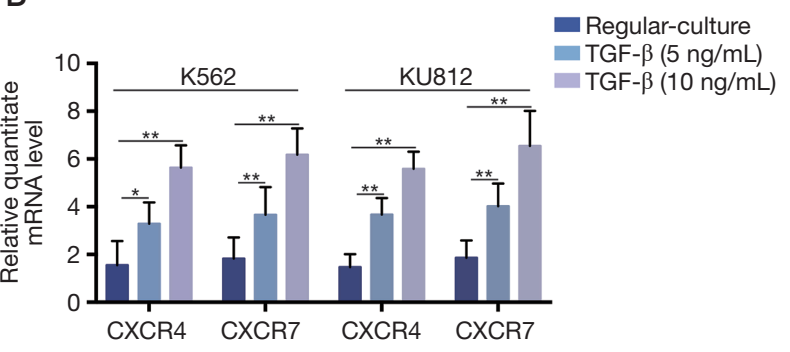

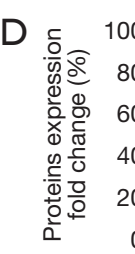

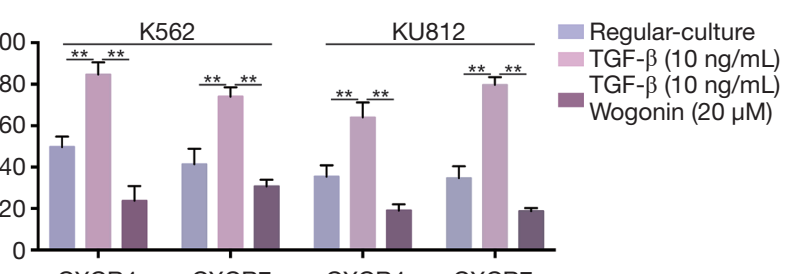

$E$

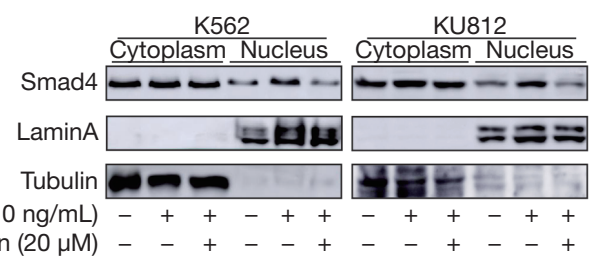

G Wogonin $(20 \mu \mathrm{M})--+--+--+--+$
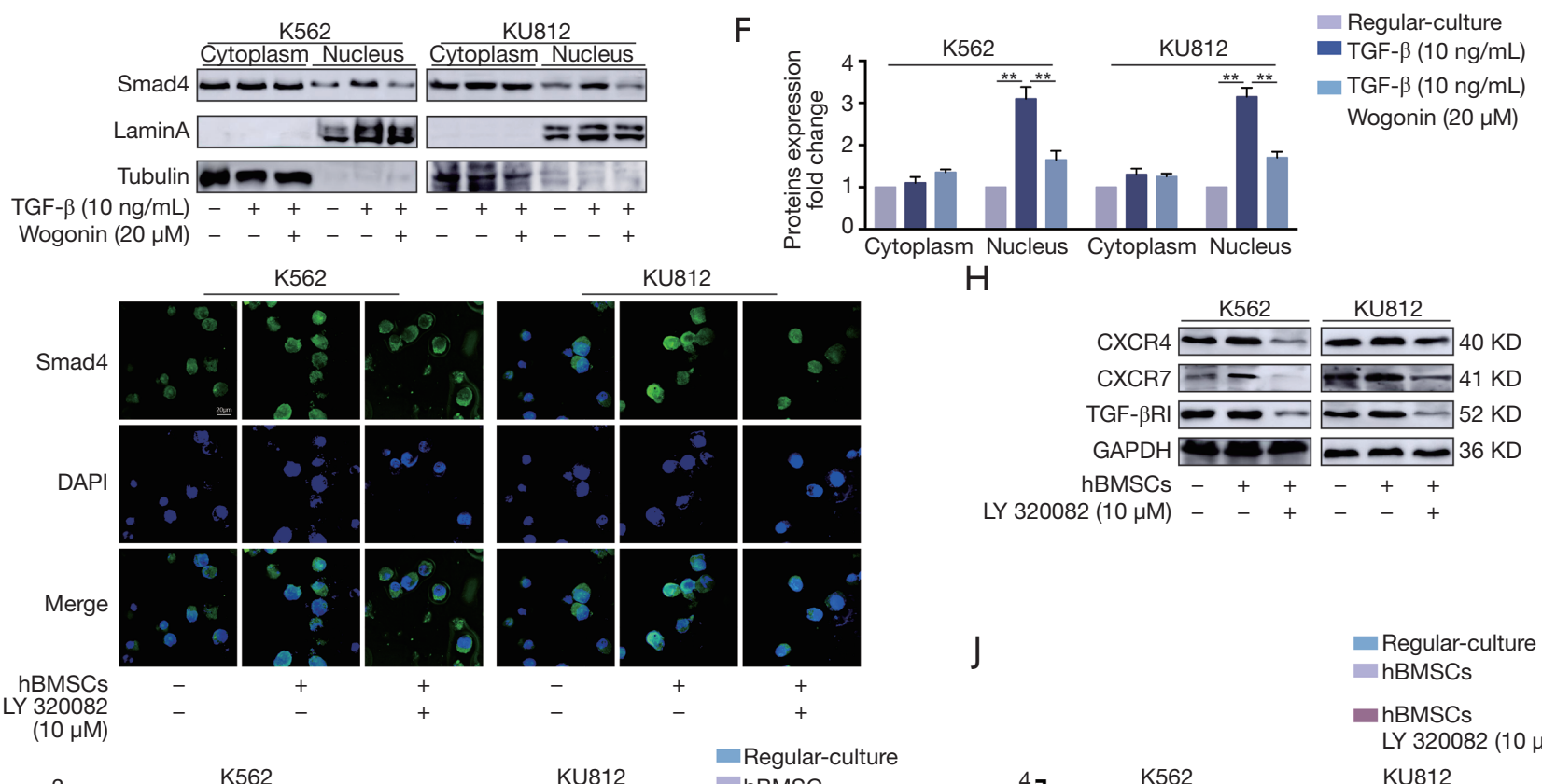

$\mathrm{H}$
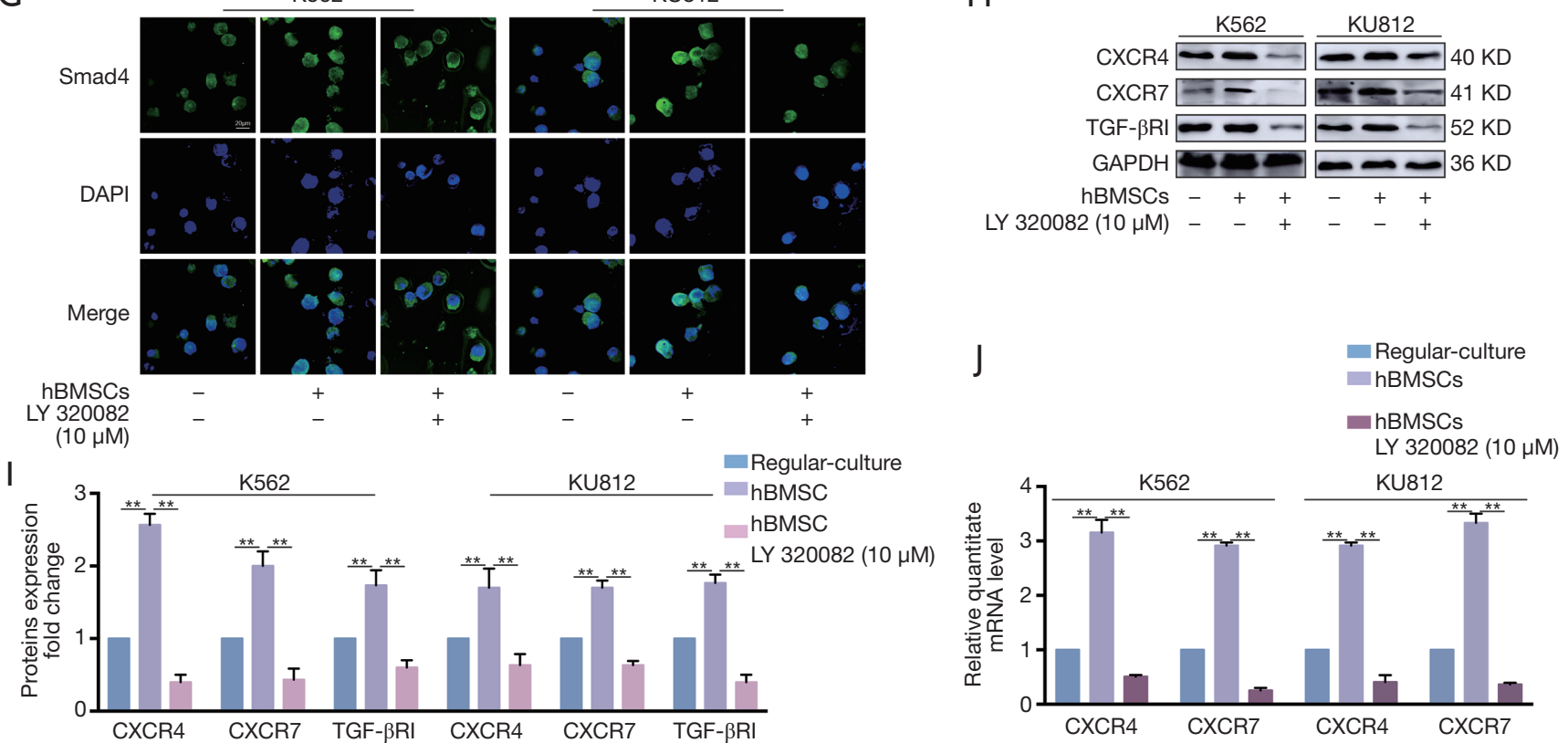

Figure 3 The secretion of TGF- $\beta$ could regulate CXCR4 and CXCR7. (A) Detection of TGF- $\beta$ secretion by ELISA assay in CML cells regular culture and co-cultured with hBMSCs. (B) Effect on the mRNA expression of CXCR4 and CXCR7 were investigated by RT-PCR in TGF- $\beta$-treated CML cells. (C,D) Western blot analysis of CXCR4 and CXCR7 in CML cells treated with $10 \mathrm{ng}$ TGF- $\beta$ or $20 \mu \mathrm{M}$ Wogonin. (E,F) Western blot analysis of Smad4 in CML cells in nuclear and cytoplasm, respectively. (G) Immunofluorescence detection of the distribution of Smad4 in CML cells treated with $10 \mu \mathrm{M} \mathrm{LY}$ 320082, inhibitor of TGF- $\beta$ RI (original magnification, $\times 40$ ). (H,I) Western blot analysis of CXCR4 and CXCR7 in CML cells regular culture or co-cultured with hBMSCs or $10 \mathrm{ng}$ TGF- $\beta$-treated. (J) CXCR4 and CXCR7 mRNA expression in CML cells regular culture and co-cultured with hBMSCs or $10 \mathrm{ng}$ TGF- $\beta$-treated was detected by RT-PCR assay. *, $\mathrm{P}<0.05$; **, $\mathrm{P}<0.01$. hBMSCs, human bone marrow stromal cells; CML, chronic myeloid leukemia; TGF- $\beta$ RI, TGF- $\beta$ receptor type I. 
A

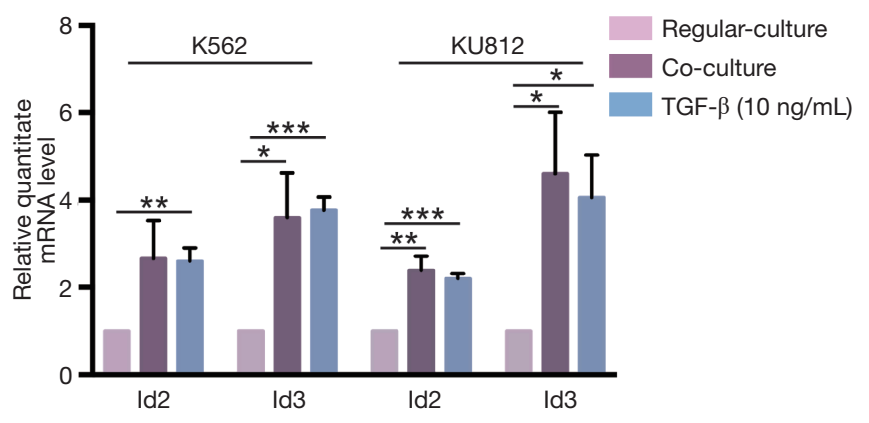

B

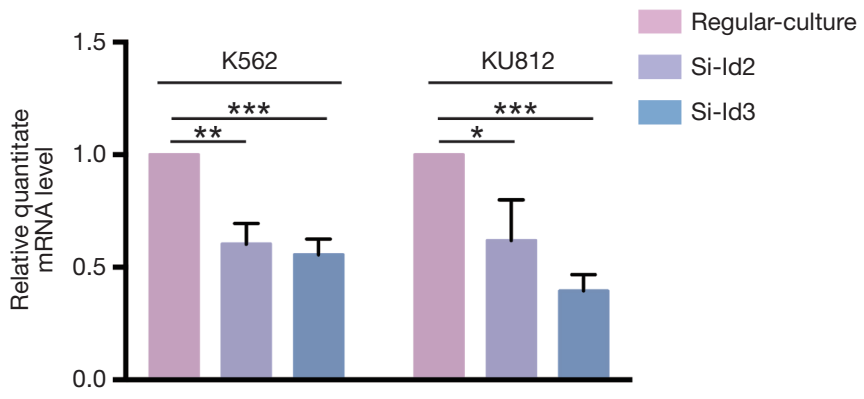

C

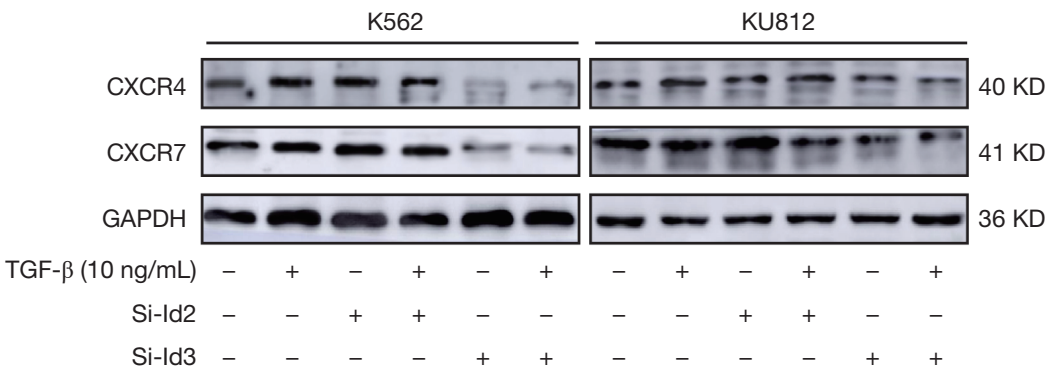

\begin{tabular}{l|l|l}
\hline Regular-culture & Si-Id2 & Si-Id2 + TGF- $\beta(10 \mathrm{ng} / \mathrm{mL})$ \\
TGF- $\beta(10 \mathrm{ng} / \mathrm{mL})$ & Si-ld3 & Si-Id3 + TGF- $\beta(10 \mathrm{ng} / \mathrm{mL})$
\end{tabular}

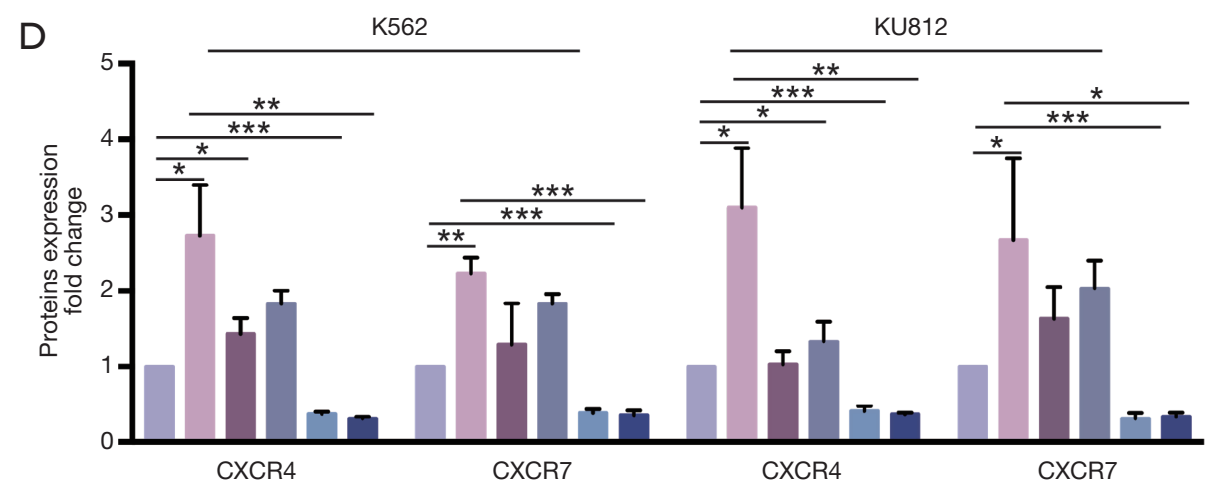

Figure 4 The Id3 gene could regulate CXCR4 and CXCR7. (A) Id2 and Id3 genes in CML cells were investigated by RT-PCR in 10 ng TGF- $\beta$-treated or co-cultured with hBMSCs CML cells. (B) RT-PCR assay detection after CML cells being treated with Id2 siRNA or Id3 siRNA in CML cells. (C,D) Western blot analysis of CXCR4 and CXCR7 in CML cells treated with Id2 siRNA or Id3 siRNA with or without 10 ng TGF- $\beta$. *, $\mathrm{P}<0.05$; $^{* *}, \mathrm{P}<0.01{ }^{* * *}, \mathrm{P}<0.0001$. hBMSCs, human bone marrow stromal cells; CML, chronic myeloid leukemia. 


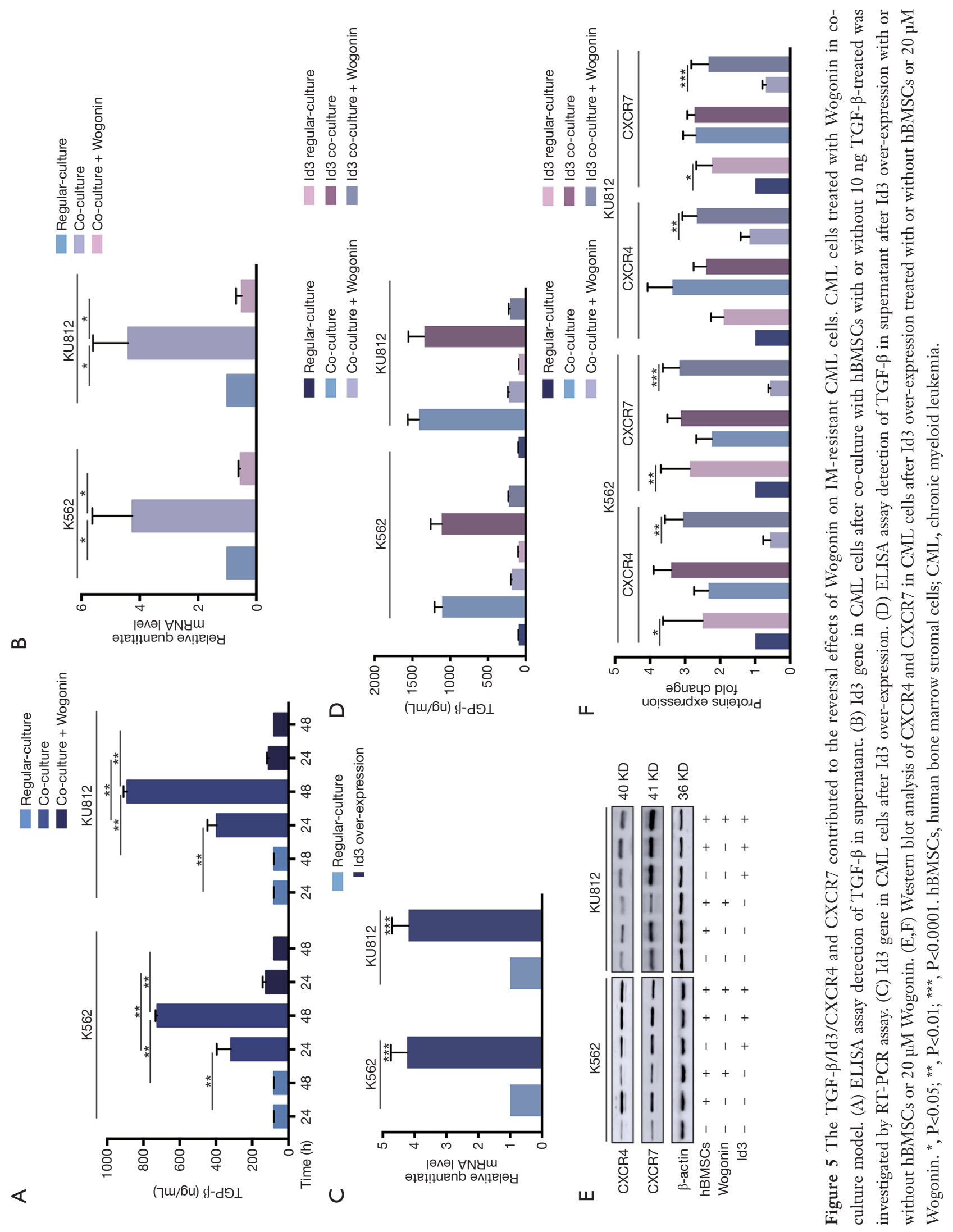


A

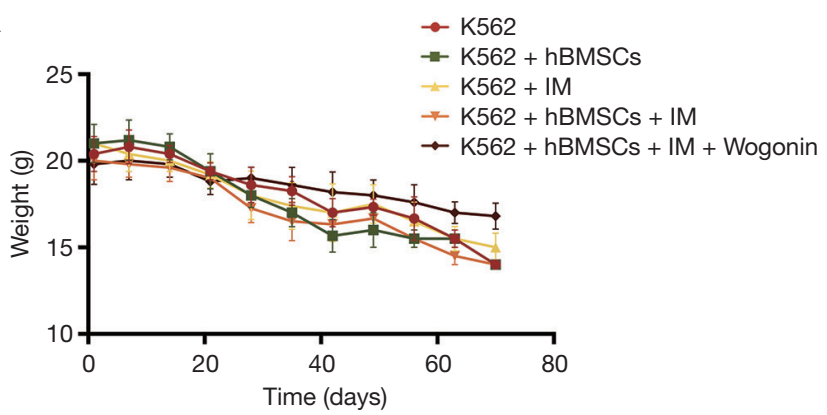

C

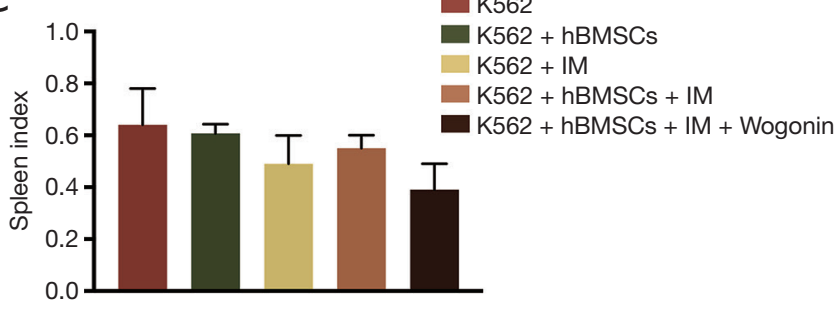

E

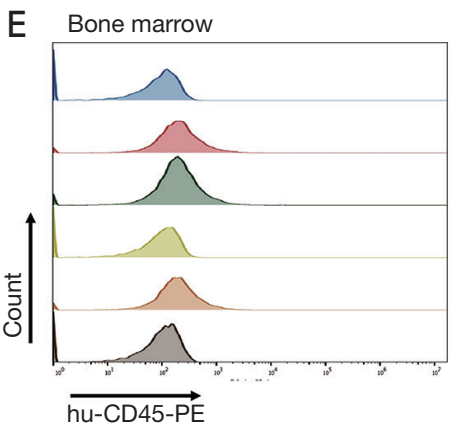

$\square$ Control

$\square \mathrm{K} 562$

$\square \mathrm{K} 562+\mathrm{IM}$

$\square \mathrm{K} 562+\mathrm{hBMSCs}+\mathrm{IM}$

$\square \mathrm{K} 562$ + hBMSCs + IM + Wogonin
B

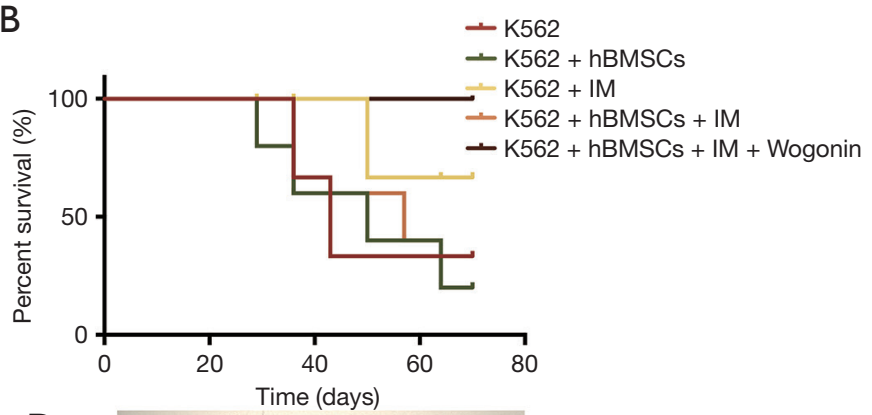

D
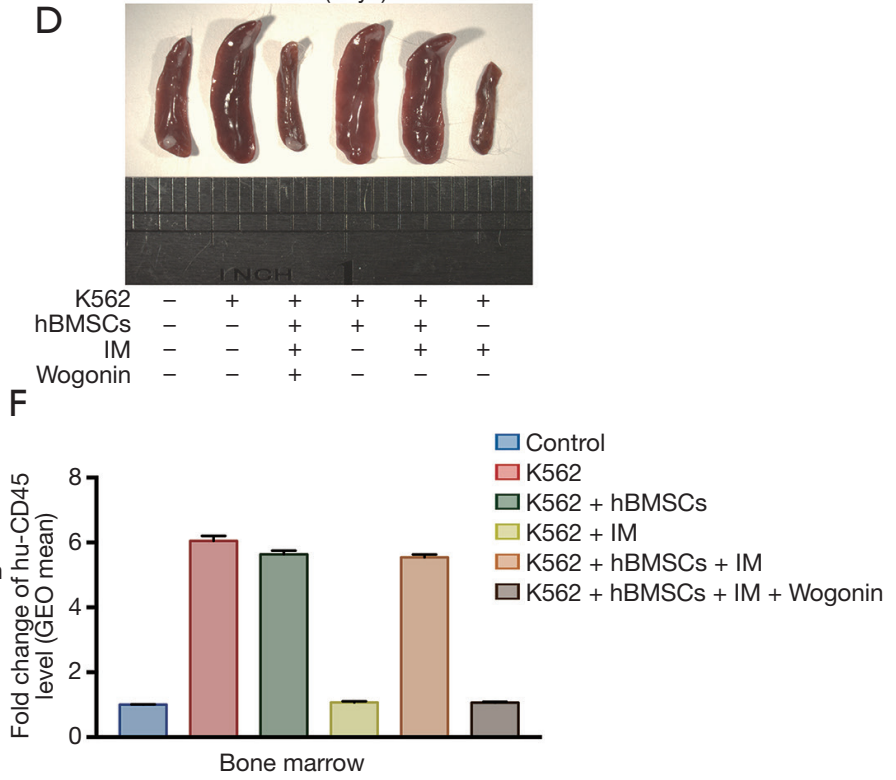

G
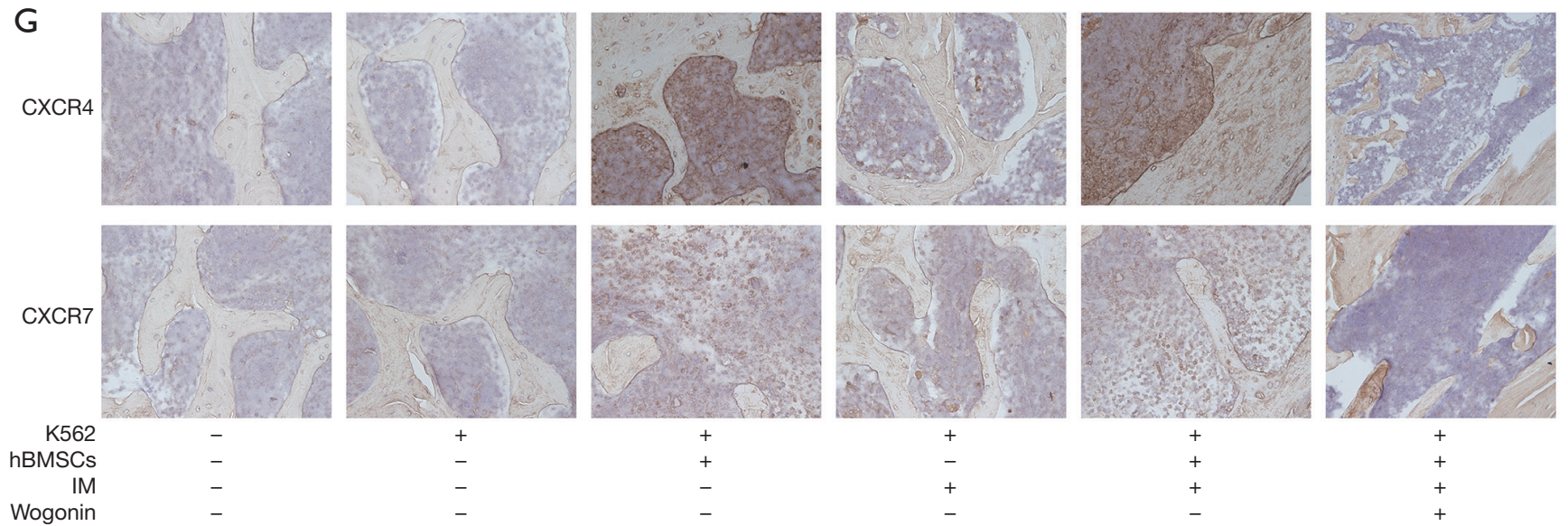

Figure 6 The reversal effect and mechanisms of Wogonin in vivo. Tumor xenografts inoculated with K562 cells or combinations with hBMSCs were treated with IM $(200 \mathrm{mg} / \mathrm{kg})$ or combination with Wogonin $(60 \mathrm{mg} / \mathrm{kg})$ every other day orally for 4 weeks. (A) The analysis of body weight after indicated. (B) Survival curves of mice after different treatment. (C) The weight of spleens of treatment groups. (D) Images of representative spleens. (E,F) The changes of $\mathrm{CD} 45^{+}$population after different treatment was detected by flow cytometry, cells were separated from mice bone marrow. (G) Representative IHC staining of murine BM, for human CXCR4 and CXCR7 antigen after different treatment (original magnification, $\times 60$ ). IM, imatinib; hBMSCs, human bone marrow stromal cells; BM, bone marrow. 


\section{Discussion}

The BME not only supports normal and hematopoietic cells, but also serves as a refuge for tumor cells, protecting them from the effects of chemotherapeutic agents. The BMSCs and the secretion of various factors in BME could promote the proliferation, survival and differentiation of hematopoietic cells (31). Soluble factors, such as stromal cell derived factor-1 (or CXCL12), interleukin-6 (IL-6), TGF- $\beta$ could participate in a variety of physiological activities of tumor cells to regulate the tumor cell's sensitivity to chemotherapy drugs.

Based on our previous researches, this study focused on the mechanism by which Wogonin increases the sensitivity of CML cells to IM in the BME. In this article, we cocultured CML cells with BMSCs in vitro to establish BME model and determined that the sensitivity of CML cells to IM in co-culture group was significantly reduced, which was caused by the secretion of TGF- $\beta$ and up-regulation of the CXCR4 and CXCR7 expression. In addition, BMSCs can modulate the state of CXCR4 and CXCR7 axis via TGF- $\beta$ secretion, switching them from resting state to active state. It has been found that the high expression of CXCR4 and CXCR7 is highly correlated with the metastasis and progression of leukemia in many clinical studies. The activation of CXCR4 in leukemia cells has been shown to promote cell proliferation, metastasis and other activities through downstream pathways of CXCR4 such as PI3K/ AKT/FOXO3A, ERK/MAPK, NF- $\kappa$ B, and STAT3 $(32,33)$. Recent research showed that activation of CXCR7 could significantly increase cell proliferation and inhibits apoptosis induced by cytotoxic drugs (34-38).

On the other hand, higher level of TGF- $\beta$ is found in bone marrow samples from patients with leukemia, such as multiple myeloma and B-cell lymphocytic leukemia $(39,40)$. TGF- $\beta$ is one of the important soluble factors in the BME. In the present study we used the BMSCs, a cell line which could secrete TGF- $\beta$, to investigate whether CXCR4 and CXCR7 expression could be regulated by TGF- $\beta$. We show here that TGF- $\beta$ up-regulated the expression of CXCR4 and CXCR7 in CML cells as detected in the BME or exogenous TGF- $\beta$. Moreover, LY 320082, the inhibitor of TGF- $\beta$, can significantly reduce the expression of CXCR4 and CXCR7 in the BME.

Ids, a small family of helix-loop-helix factors, regulate a myriad of cellular functions including cell proliferation, survival, invasion and metastasis. Studies have shown that Id4 gene is silenced by hypermethylation in leukemia cells
(41-43). Our results demonstrated that the expression of Id4 in CML cells with co-culture group were very low (data not shown). We believe that Ids, as a downstream effector of TGF- $\beta$, may be involved in the regulation of CXCR4/7 by TGF- $\beta$. We hypothesize that the responsible mechanism was due to elevated Id 3 expression. In our model, the expression of CXCR4 and CXCR7 are upregulated by Id 3 expression. Since the regulation of CXCR4 and CXCR7 expression by other factors could not be ruled out, we need to further probe the mechanism of CXCR4 and CXCR7 expression in CML cells in the future.

Wogonin shows effective anticancer activities and lowtoxicities both in vivo and in vitro. In this study, Wogonin could destroy the protective effect of BME on CML cells and increase the rate of IM-induced apoptosis. The results of animal experiments showed that the combination of Wogonin and IM could significantly reduce the number of CML cells in vivo. Immunohistochemical staining of the thigh bones of mice in each group revealed that CXCR4 and CXCR7 were lower expressed in the combined administration group compared with IM alone group under co-culture, suggesting that Wogonin might play a role in reversing drug resistance by inhibiting the expression of CXCR4 and CXCR7. The results of Wogonin in vivo were consistent with those in vitro. Still, as a multi-target compound, Wogonin must have other mechanisms to reverse drug resistance.

In summary, our research demonstrated that Wogonin could significantly enhance the sensitivity of CML cells to IM in the co-culture model. The mechanisms of Wogonin on improving the sensitivity of CML cells to IM might be related to inhibiting the secretion of TGF- $\beta$ in the BME and disrupting the activation of the CXCL12-CXCR4/7 axis. Therefore, Wogonin could be a novel and potent agent to eliminate leukemia resistance in the future.

\section{Acknowledgments}

Funding: This work was supported by the National Natural Science Foundation of China (No. 81673461, 81873046 and 81830105,81773774$)$, the Drug Innovation Major Project (No. 2017ZX09301014, 2018ZX09711001-003007), the Project Program of State Key Laboratory of Natural Medicines, China Pharmaceutical University (No. SKLNMZZCX201823), the Social Development Project of Jiangsu Provincial Science and Technology Department (No. BE2018711), and the "Double First-Class" University 
project (No. CPU 2018GF11, CPU2018GF05).

\section{Footnote}

Reporting Checklist: The authors have completed the ARRIVE reporting checklist. Available at http://dx.doi. org/10.21037/atm-20-1166

Data Sharing Statement: Available at http://dx.doi. org/10.21037/atm-20-1166

Conflicts of Interest: All authors have completed the ICMJE uniform disclosure form (available at http://dx.doi. org/10.21037/atm-20-1166). Dr. QG reports a patent ZL 200510095341.2 pending. The other authors have no conflicts of interest to declare.

Ethical Statement: The authors are accountable for all aspects of the work in ensuring that questions related to the accuracy or integrity of any part of the work are appropriately investigated and resolved. BMSCs were isolated from the iliac crest BM aspirates of healthy donors after informed consent was obtained. The study was conducted in accordance with the Declaration of Helsinki (as revised in 2013). The study was approved by Nanjing Drum Tower Hospital's institutional review board. The animal study was carried out according to the regulations of China Food and Drug Administration (CFDA) on Animal Care. This study was reviewed and approved by Animal Care Use Committee of Jiangsu Province (Animal authorization reference number: SYXK2012-0035).

Open Access Statement: This is an Open Access article distributed in accordance with the Creative Commons Attribution-NonCommercial-NoDerivs 4.0 International License (CC BY-NC-ND 4.0), which permits the noncommercial replication and distribution of the article with the strict proviso that no changes or edits are made and the original work is properly cited (including links to both the formal publication through the relevant DOI and the license). See: https://creativecommons.org/licenses/by-nc-nd/4.0/.

\section{References}

1. Druker BJ, Sawyers CL, Kantarjian H, et al. Activity of a specific inhibitor of the BCR-ABL tyrosine kinase in the blast crisis of chronic myeloid leukemia and acute lymphoblastic leukemia with the Philadelphia chromosome. N Engl J Med 2001;344:1038-42.

2. Cagnetta A, Garuti A, Marani C, et al. Evaluating treatment response of chronic myeloid leukemia: emerging science and technology. Curr Cancer Drug Targets 2013;13:779-90.

3. Cortes JE, Nicolini FE, Wetzler M, et al. Subcutaneous omacetaxine mepesuccinate in patients with chronic-phase chronic myeloid leukemia previously treated with 2 or more tyrosine kinase inhibitors including imatinib. Clin Lymphoma Myeloma Leuk 2013;13:584-91.

4. Ma L, Shan Y, Bai R, et al. A therapeutically targetable mechanism of BCR-ABL-independent imatinib resistance in chronic myeloid leukemia. Sci Transl Med 2014;6:252ra121.

5. Jin L, Hope KJ, Zhai Q, et al. Targeting of CD44 eradicates human acute myeloid leukemic stem cells. Nat Med 2006;12:1167-74.

6. Zhang B, Li M, McDonald T, et al. Microenvironmental protection of CML stem and progenitor cells from tyrosine kinase inhibitors through $\mathrm{N}$-cadherin and Wntbeta-catenin signaling. Blood 2013;121:1824-38.

7. Ashley DM, Bol SJ, Kannourakis G. Human bone marrow stromal cell contact and soluble factors have different effects on the survival and proliferation of paediatric B-lineage acute lymphoblastic leukaemic blasts. Leuk Res 1994;18:337-46.

8. Azab AK, Quang P, Azab F, et al. P-selectin glycoprotein ligand regulates the interaction of multiple myeloma cells with the bone marrow microenvironment. Blood 2012;119:1468-78.

9. Azab AK, Azab F, Blotta S, et al. RhoA and Rac1 GTPases play major and differential roles in stromal cell-derived factor-1-induced cell adhesion and chemotaxis in multiple myeloma. Blood 2009;114:619-29.

10. Azab AK, Azab F, Quang P, et al. FGFR3 is overexpressed waldenstrom macroglobulinemia and its inhibition by Dovitinib induces apoptosis and overcomes stromainduced proliferation. Clin Cancer Res 2011;17:4389-99.

11. Konopleva M, Konoplev S, Hu W, et al. Stromal cells prevent apoptosis of AML cells by up-regulation of antiapoptotic proteins. Leukemia 2002;16:1713-24.

12. Ishibe N, Albitar M, Jilani IB, et al. CXCR4 expression is associated with survival in familial chronic lymphocytic leukemia, but CD38 expression is not. Blood 2002;100:1100-1.

13. Krieglstein K, Rufer M, Suter-Crazzolara C, et al. Neural functions of the transforming growth factors beta. Int J Dev Neurosci 1995;13:301-15. 
14. Tsuchida K, Nakatani M, Yamakawa N, et al. Activin isoforms signal through type I receptor serine/threonine kinase ALK7. Mol Cell Endocrinol 2004;220:59-65.

15. Wang RN, Green J, Wang Z, et al. Bone Morphogenetic Protein (BMP) signaling in development and human diseases. Genes Dis 2014;1:87-105.

16. Chen Y, Lebrun JJ, Vale W. Regulation of transforming growth factor beta- and activin-induced transcription by mammalian Mad proteins. Proc Natl Acad Sci U S A 1996;93:12992-7.

17. Shi Y, Massague J. Mechanisms of TGF-beta signaling from cell membrane to the nucleus. Cell 2003;113:685-700.

18. Miyazono K, Miyazawa K. Id: a target of BMP signaling. Sci STKE 2002;2002:pe40.

19. Ruzinova MB, Benezra R. Id proteins in development, cell cycle and cancer. Trends Cell Biol 2003;13:410-8.

20. Tai MC, Tsang SY, Chang LY, et al. Therapeutic potential of wogonin: a naturally occurring flavonoid. CNS Drug Rev 2005;11:141-50.

21. Chi YS, Lim H, Park H, et al. Effects of wogonin, a plant flavone from Scutellaria radix, on skin inflammation: in vivo regulation of inflammation-associated gene expression. Biochem Pharmacol 2003;66:1271-8.

22. Xu X, Zhang X, Liu Y, et al. BM microenvironmental protection of CML cells from imatinib through Stat5/NFkappaB signaling and reversal by Wogonin. Oncotarget 2016;7:24436-54.

23. Xu X, Zhang X, Zhang Y, et al. Wogonin reversed resistant human myelogenous leukemia cells via inhibiting Nrf2 signaling by Stat3/NF-kappaB inactivation. Sci Rep 2017;7:39950.

24. Vianello F, Villanova F, Tisato V, et al. Bone marrow mesenchymal stromal cells non-selectively protect chronic myeloid leukemia cells from imatinib-induced apoptosis via the CXCR4/CXCL12 axis. Haematologica 2010;95:1081-9.

25. Cao H, Li W, Zhou Y, et al. Oroxylin a Inhibits the Protection of Bone Marrow Microenvironment on CML Cells Through CXCL12/CXCR4/P-gp Signaling Pathway. Front Oncol 2019;9:188.

26. Jin L, Tabe Y, Konoplev S, et al. CXCR4 up-regulation by imatinib induces chronic myelogenous leukemia (CML) cell migration to bone marrow stroma and promotes survival of quiescent CML cells. Mol Cancer Ther 2008;7:48-58.

27. Weisberg E, Azab AK, Manley PW, et al. Inhibition of CXCR4 in CML cells disrupts their interaction with the bone marrow microenvironment and sensitizes them to nilotinib. Leukemia 2012;26:985-90.

28. Chu CY, Sheen YS, Cha ST, et al. Induction of chemokine receptor CXCR4 expression by transforming growth factor-beta1 in human basal cell carcinoma cells. J Dermatol Sci 2013;72:123-33.

29. DiVito KA, Simbulan-Rosenthal CM, Chen YS, et al. Id2, Id 3 and Id4 overcome a Smad7-mediated block in tumorigenesis, generating TGF-beta-independent melanoma. Carcinogenesis 2014;35:951-8.

30. Li W, Ding Q, Ding Y, et al. Oroxylin A reverses the drug resistance of chronic myelogenous leukemia cells to imatinib through CXCL12/CXCR7 axis in bone marrow microenvironment. Mol Carcinog 2017;56:863-76.

31. Clark BR, Keating A. Biology of bone marrow stroma. Bone Marrow Transplantation: Foundations for the 21st Century 1995;770:70-8.

32. Cui C, Wang P, Cui N, et al. Sulfated polysaccharide isolated from the sea cucumber Stichopus japonicas promotes the SDF-1 $\alpha / \mathrm{CXCR} 4$ axis-induced NSC migration via the PI3K/Akt/FOXO3a, ERK/MAPK, and NF- $\kappa \mathrm{B}$ signaling pathways. Neurosci Lett 2016;616:57-64.

33. Jung MJ, Rho JK, Kim YM, et al. Upregulation of CXCR4 is functionally crucial for maintenance of stemness in drug-resistant non-small cell lung cancer cells. Oncogene 2013;32:209-21.

34. Burns JM, Summers BC, Wang Y, et al. A novel chemokine receptor for SDF-1 and I-TAC involved in cell survival, cell adhesion, and tumor development. J Exp Med 2006;203:2201-13.

35. Hattermann K, Held-Feindt J, Lucius R, et al. The chemokine receptor CXCR7 is highly expressed in human glioma cells and mediates antiapoptotic effects. Cancer Res 2010;70:3299-308.

36. Raggo C, Ruhl R, McAllister S, et al. Novel cellular genes essential for transformation of endothelial cells by Kaposi's sarcoma-associated herpesvirus. Cancer Res 2005;65:5084-95.

37. Tripathi V, Verma R, Dinda A, et al. Differential expression of RDC1/CXCR7 in the human placenta. J Clin Immunol 2009;29:379-86.

38. Wang J, Shiozawa Y, Wang J, et al. The role of CXCR7/ RDC1 as a chemokine receptor for CXCL12/SDF-1 in prostate cancer. J Biol Chem 2008;283:4283-94.

39. Lagneaux L, Delforge A, Dorval C, et al. Excessive Production of Transforming Growth-Factor-Beta by Bone-Marrow Stromal Cells in B-Cell Chronic Lymphocytic-Leukemia Inhibits Growth of Hematopoietic Precursors and Interleukin-6 Production. Blood 
1993;82:2379-85.

40. Urashima M, Ogata A, Chauhan D, et al. Transforming growth factor-beta 1: Differential effects on multiple myeloma versus normal B cells. Blood 1996;87:1928-38.

41. Carey JP, Asirvatham AJ, Galm O, et al. Inhibitor of differentiation 4 (Id4) is a potential tumor suppressor in prostate cancer. BMC Cancer 2009;9:173.

42. Martini M, Cenci T, D'Alessandris GQ, et al. Epigenetic

Cite this article as: Cao H, Gao Y, Wang R, Guo Q, Hui H. Wogonin reverses the drug resistance of chronic myelogenous leukemia cells to imatinib through CXCL12-CXCR4/7 axis in bone marrow microenvironment. Ann Transl Med 2020;8(17):1046. doi: 10.21037/atm-20-1166 silencing of Id4 identifies a glioblastoma subgroup with a better prognosis as a consequence of an inhibition of angiogenesis. Cancer 2013;119:1004-12.

43. Yu L, Liu C, Vandeusen J, et al. Global assessment of promoter methylation in a mouse model of cancer identifies ID4 as a putative tumor-suppressor gene in human leukemia. Nat Genet 2005;37:265-74. 